Article

\title{
Synthesis and Antimycobacterial Activity of 3-Phenyl-1H-indoles
}

\author{
Renata Jardim Etchart ${ }^{1,2}$, Raoní S. Rambo ${ }^{1}\left(\mathbb{D}\right.$, Bruno Lopes Abbadi ${ }^{1}{ }^{\circledR}$, Nathalia Sperotto ${ }^{1}$, Christiano Ev Neves ${ }^{1,2}$, \\ Fernanda Fries Silva ${ }^{1,2}$, Maiele Dornelles ${ }^{1}$, Lovaine Duarte ${ }^{1}$, Fernanda Souza Macchi ${ }^{1,2}$, Marcia Alberton Perelló ${ }^{1}$, \\ Rogério Vescia Lourega $^{3(\mathbb{D}}$, Cristiano Valim Bizarro ${ }^{1,2} \mathbb{( 0}$, Luiz Augusto Basso ${ }^{1,2,4}$ and Pablo Machado ${ }^{1,2,4, *(1)}$
}

1 Centro de Pesquisas em Biologia Molecular e Funcional, Instituto Nacional de Ciência e Tecnologia em Tuberculose, Pontifícia Universidade Católica do Rio Grande do Sul, Avenida Ipiranga, 6681-Prédio 92A, Porto Alegre 90616-900, RS, Brazil; renata.etchart@gmail.com (R.J.E.); raoni.rambo@gmail.com (R.S.R.); br.abbadi@gmail.com (B.L.A.); nathalia.sperotto@gmail.com (N.S.); christiano_neves@hotmail.com (C.E.N.); fernanda.fries@acad.pucrs.br (F.F.S.); maieledornelles@gmail.com (M.D.); lovaduarte@gmail.com (L.D.); fernanda.macchi@outlook.com (F.S.M.); marcia.perello@pucrs.br (M.A.P.); cristiano.bizarro@pucrs.br (C.V.B.); luiz.basso@pucrs.br (L.A.B.)

2 Programa de Pós-Graduação em Biologia Celular e Molecular, Pontifícia Universidade Católica do Rio Grande do Sul, Porto Alegre 90616-900, RS, Brazil

3 Instituto de Química, Departamento de Química, Universidade Federal do Rio Grande do Sul, Porto Alegre 91501-970, RS, Brazil; louregarv@gmail.com

4 Programa de Pós-Graduação em Medicina e Ciências da Saúde, Pontifícia Universidade Católica do Rio Grande do Sul, Porto Alegre 90616-900, RS, Brazil

* Correspondence: pablo.machado@pucrs.br; Tel./Fax: +55-51-3320-3629

check for

updates

Citation: Jardim Etchart, R.; Rambo, R.S.; Lopes Abbadi, B.; Sperotto, N.;

Ev Neves, C.; Fries Silva, F.; Dornelles,

M.; Duarte, L.; Souza Macchi, F.;

Alberton Perelló, M.; et al. Synthesis and Antimycobacterial Activity of 3-Phenyl-1H-indoles. Molecules 2021, 26, 5148. https://doi.org/10.3390/ molecules26175148

Academic Editor: Fawaz Aldabbagh

Received: 27 July 2021

Accepted: 23 August 2021

Published: 25 August 2021

Publisher's Note: MDPI stays neutral with regard to jurisdictional claims in published maps and institutional affiliations.

Copyright: (C) 2021 by the authors Licensee MDPI, Basel, Switzerland. This article is an open access article distributed under the terms and conditions of the Creative Commons Attribution (CC BY) license (https:/ / creativecommons.org/licenses/by/ $4.0 /)$.
Abstract: Tuberculosis has been described as a global health crisis since the 1990s, with an estimated 1.4 million deaths in the last year. Herein, a series of $201 H$-indoles were synthesized and evaluated as in vitro inhibitors of Mycobacterium tuberculosis (Mtb) growth. Furthermore, the top hit compounds were active against multidrug-resistant strains, without cross-resistance with first-line drugs. Exposing HepG2 and Vero cells to the molecules for $72 \mathrm{~h}$ showed that one of the evaluated structures was devoid of apparent toxicity. In addition, this 3-phenyl- $1 H$-indole showed no genotoxicity signals. Finally, time-kill and pharmacodynamic model analyses demonstrated that this compound has bactericidal activity at concentrations close to the Minimum Inhibitory Concentration, coupled with a strong time-dependent behavior. To the best of our knowledge, this study describes the activity of 3-phenyl-1H-indole against Mtb for the first time.

Keywords: $1 H$-indoles; Mycobacterium tuberculosis; mammalian cellular viability; genotoxicity; timekill; pharmacodynamic model

\section{Introduction}

Tuberculosis (TB) is an ancient disease, dating back to 70,000 years ago, and remains a global public health emergency causing more than 1 million deaths each year. According to the WHO Global Tuberculosis Report (2020), an estimated 10.0 million people fell ill with TB in 2019, with 1.2 million deaths among HIV-negative people and an additional 208,000 deaths among HIV-positive people [1].

After initial exposure, the intracellular pathogen Mycobacterium tuberculosis (Mtb), the causative agent of human TB, is absorbed by the alveolar macrophages of the lung. At this point, most infections are eliminated by a functioning immune system. If there is uncontrolled bacterial replication, a primary infection is established. This can develop into an active infection, which can lead to the development of symptoms of the disease (cough, night sweats, weight loss, and so forth) [2].

The first-line treatment of TB consists of a regimen of four drugs (isoniazid, rifampicin, ethambutol, and pyrazinamide), lasting 6 months. TB is a particularly challenging disease, with rapid development of resistant strains, mainly attributed to the low adherence to treatment protocols. Multidrug-resistant TB (MDR-TB) is caused by bacilli that are resistant 
to at least isoniazid and rifampin, whereas extensively drug-resistant TB (XDR-TB) is occasioned by resistant strains to isoniazid and rifampin, plus any fluoroquinolone and at least one of three injectable second-line drugs [3,4].

The discovery of drugs such as isoniazid and pyrazinamide (discovered in the early 1950s), ethambutol and rifampicin (discovered in the 1960s) remains the basis of anti-TB therapy. After 1960, there was no completely new drug to treat TB until bedaquiline was approved in 2012 [5,6]. A few years later, the drugs delamanid (2014) and pretomanid (2019) were also approved. These three approved drugs received indications for the treatment of MDR-TB [2,4].

Despite the capacity of these new pharmacological alternatives to treat TB, the high capability for adaptation and the development of mutations associated with resistance [7] have highlighted the importance of continuous efforts to discover and develop new anti-TB drugs. Our research group has synthesized and evaluated different heterocyclic compounds against drug-susceptible and drug-resistant Mtb strains, with some encouraging results [8-10]. Importantly, the indole scaffold has been described in compounds endowed with antitubercular activity [11]. Additionally, this heterocycle has been obtained in molecules with antiviral, anti-inflammatory, antinociceptive, anticancer, anti-HIV, antioxidant, antimicrobial, antidiabetic, antimalarial, and anticholinesterase activities [12]. However, to the best of our knowledge, 3-phenyl- $1 \mathrm{H}$-indoles have not yet been evaluated as possible inhibitors of Mtb growth.

Within this context, the present study describes the synthesis of 3-phenyl- $1 \mathrm{H}$-indoles and their in vitro activity against drug-susceptible and drug-resistant Mtb strains. Additionally, apparent cytoxicity and genotoxicity were studied using mammalian cells. Finally, antimycobacterial kinetic behavior was also shown, with concomitant exploration of a pharmacodynamic model.

\section{Results}

Compounds were synthesized by a well-established protocol for direct arylation of $\mathrm{NH}$ indoles [13]. The method was highly regioselective, allowing 3-phenyl- $1 H$-indoles to be obtained in a catalytic system based on palladium(II) acetate/bis(diphenylphosphino)methane $\left[\mathrm{Pd}(\mathrm{OAc})_{2} / \mathrm{dppm}\right]$ using water as solvent. The palladium-catalyzed procedure led to $\mathrm{C}-\mathrm{H}$ functionalization of indoles $\mathbf{1}$, with aryl halides $\mathbf{2}$ leading to the desired compounds $\mathbf{3 a - t}$ with $10-77 \%$ yields after purification (Scheme 1). The spectroscopic and spectrometric data obtained were in full agreement with the proposed structures (Section 3.2 and Supplementary Materials Figures S1-S40).

The synthesized 3-phenyl- $1 \mathrm{H}$-indoles $3 \mathbf{a}-\mathbf{t}$ were evaluated in a whole-cell assay against the Mtb H37Rv strain using isoniazid as positive control [9] (Scheme 1). Under our experimental conditions, this first-line drug presented a Minimum Inhibitory Concentration (MIC) of $2.3 \mu \mathrm{M}$. In general, the MIC values exhibited by the compounds seemed to have a low correlation with the electronic and physicochemical characteristics of the substituents. The results indicated that steric components seem to be more important in explaining, even partially, the bacterial growth inhibition potencies.

The unsubstituted molecule $3 \mathbf{a}$ was inactive at the highest concentration evaluated $(129.4 \mu \mathrm{M})$. The presence of a methyl group at the 4-position of the benzene ring also provided an inactive structure, as the $1 \mathrm{H}$-indole $3 \mathbf{b}$ presented a MIC $>120.6 \mu \mathrm{M}$. The increase in molecular volume with the concomitant insertion of an atom that can act as a hydrogen bond acceptor increased antimycobacterial activity since the 4-methoxycontaining compound 3c exhibited a MIC value of $28.0 \mu \mathrm{M}$. By contrast, the presence of a substituent with a reduced molecular volume and electron withdrawing character attached at the 4-position of the benzene ring reduced the molecular ability to inhibit Mtb growth. The fluorinated structure 3d showed a MIC value of $94.7 \mu \mathrm{M}$. Interestingly, when the fluorine atom was replaced with a trifluoromethyl group in the $1 \mathrm{H}$-indole $3 \mathbf{e}$, the antimycobacterial activity was almost doubled, reducing the MIC value to $47.8 \mu \mathrm{M}$. 


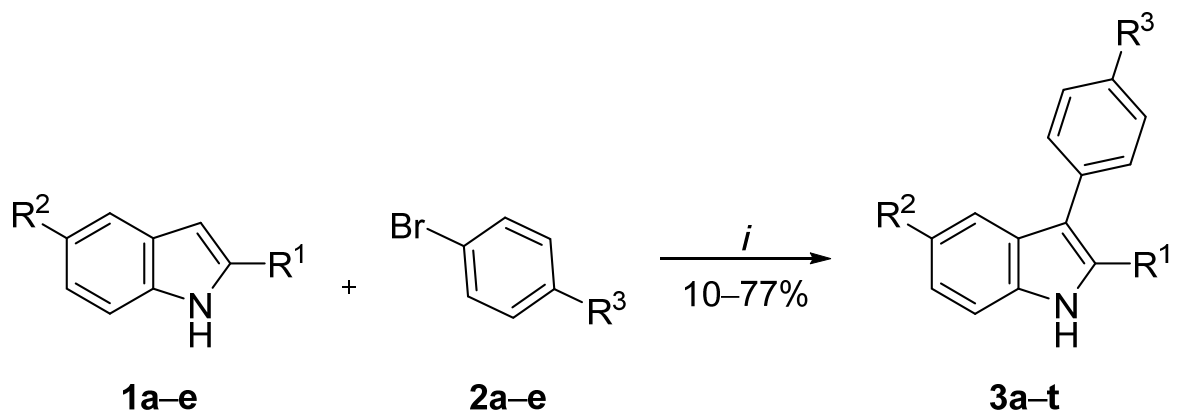

\begin{tabular}{|c|c|c|c|c|c|}
\hline Compound & $\mathbf{R}^{1}$ & $\mathbf{R}^{2}$ & $\mathbf{R}^{3}$ & Yield (\%) a & $\operatorname{MIC}(\mu \mathrm{M})^{b}$ \\
\hline $3 a$ & $\mathrm{H}$ & $\mathrm{H}$ & $\mathrm{H}$ & 77 & 129.4 \\
\hline $3 b$ & $\mathrm{H}$ & $\mathrm{H}$ & $\mathrm{CH}_{3}$ & 30 & $>120.6$ \\
\hline $3 c$ & $\mathrm{H}$ & $\mathrm{H}$ & $\mathrm{OCH}_{3}$ & 68 & 28.0 \\
\hline $3 d$ & $\mathrm{H}$ & $\mathrm{H}$ & F & 35 & 94.7 \\
\hline $3 e$ & $\mathrm{H}$ & $\mathrm{H}$ & $\mathrm{CF}_{3}$ & 69 & 47.8 \\
\hline $3 f$ & $\mathrm{CH}_{3}$ & $\mathrm{H}$ & $\mathrm{OCH}_{3}$ & 10 & 84.3 \\
\hline $3 g$ & $\mathrm{CH}_{3}$ & $\mathrm{H}$ & F & 10 & $>88.8$ \\
\hline $3 h$ & $\mathrm{CH}_{3}$ & $\mathrm{H}$ & $\mathrm{CF}_{3}$ & 16 & 18.2 \\
\hline $3 \mathbf{i}$ & $\mathrm{H}$ & $\mathrm{CH}_{3}$ & F & 20 & 44.4 \\
\hline $3 \mathbf{j}$ & $\mathrm{H}$ & $\mathrm{CH}_{3}$ & $\mathrm{CF}_{3}$ & 16 & 36.3 \\
\hline $3 k$ & $\mathrm{H}$ & $\mathrm{OCH}_{3}$ & $\mathrm{CH}_{3}$ & 58 & $>105.3$ \\
\hline 31 & $\mathrm{H}$ & $\mathrm{OCH}_{3}$ & $\mathrm{OCH}_{3}$ & 26 & 24.7 \\
\hline $3 m$ & $\mathrm{H}$ & $\mathrm{OCH}_{3}$ & F & 53 & 82.9 \\
\hline $3 n$ & $\mathrm{H}$ & $\mathrm{OCH}_{3}$ & $\mathrm{CF}_{3}$ & 43 & 17.2 \\
\hline 30 & $\mathrm{H}$ & $\mathrm{F}$ & $\mathrm{F}$ & 10 & 43.6 \\
\hline $3 p$ & $\mathrm{H}$ & $\mathrm{F}$ & $\mathrm{CF}_{3}$ & 35 & 35.8 \\
\hline $3 q$ & $\mathrm{H}$ & $\mathrm{Cl}$ & $\mathrm{H}$ & 67 & $>109.8$ \\
\hline $3 r$ & $\mathrm{H}$ & $\mathrm{Cl}$ & $\mathrm{OCH}_{3}$ & 10 & 19.4 \\
\hline $3 s$ & $\mathrm{H}$ & $\mathrm{Cl}$ & F & 21 & 20.3 \\
\hline $3 t$ & $\mathrm{H}$ & $\mathrm{Cl}$ & $\mathrm{CF}_{3}$ & 30 & 8.4 \\
\hline
\end{tabular}

Scheme 1. Reagents and conditions: $i=\mathrm{Pd}(\mathrm{OAc})_{2}$, dppm, $\mathrm{LiOH} \cdot \mathrm{H}_{2} \mathrm{O}, \mathrm{H}_{2} \mathrm{O}, 110^{\circ} \mathrm{C}, 24 \mathrm{~h}$. ${ }^{\text {a }}$ Purified products. ${ }^{\mathrm{b}} \mathrm{M}$. tuberculosis H37Rv strain. MIC = Minimum Inhibitory Concentration. Data were obtained from three independent experiments and the most frequent MIC value was showed.

In the second round of structural modifications, the presence of a methyl group at the 2-position of the heterocyclic ring was studied. Furthermore, the substituents that produced compounds with higher activity $\left(4-\mathrm{OCH}_{3}, 4-\mathrm{F}\right.$, and $\left.4-\mathrm{CF}_{3}\right)$ were kept on the benzene ring. The methoxy-substituted molecule $3 \mathbf{f}$ was able to inhibit the growth of the bacillus with a MIC of $84.3 \mu \mathrm{M}$. Once again, the presence of the fluorine atom on the benzene ring in the $\mathbf{3 g}$ structure reduced the activity. By contrast, the trifluoromethyl group attached at the 4-position of the benzene ring of the $1 \mathrm{H}$-indole $3 \mathrm{~h}$ produced a compound with a MIC of $18.2 \mu \mathrm{M}$. Comparing the inhibitory capacity of the molecules in the presence (3h) and absence (3e) of the methyl group attached at the 2-position of the indole ring, one can conclude that $3 \mathrm{~h}$ was approximately 2.6 -fold more effective than $\mathbf{3 e}$.

Finally, attention was turned to the 5-position of the indole ring. The first substituent evaluated was a methyl group at that position. Compounds $3 \mathbf{i}$ and $\mathbf{3} \mathbf{j}$, containing fluorine and trifluoromethyl group attached at the benzene ring, presented MIC values of $44.4 \mu \mathrm{M}$ and $36.3 \mu \mathrm{M}$, respectively. The methoxy group was also evaluated at the 5-position of the heterocyclic ring in molecules $3 \mathbf{k}-\mathbf{n}$. The presence of the methyl group on the benzene ring of the $3 \mathbf{k}$ structure led to an inactive compound, considering the highest evaluated concentration. This was the same pattern observed for the methylated $1 H$-indole $\mathbf{3 b}$. 
Furthermore, the dimethoxy-substituted compound 31 exhibited a MIC value of $24.7 \mu \mathrm{M}$. This activity was similar to that of the monosubstituted molecule $3 c(28.0 \mu \mathrm{M})$. When the fluorine atom replaced the methoxy group on the benzene ring, the antimycobacterial activity was reduced more than three-fold, as the MIC value of the $1 H$-indole $3 \mathrm{~m}$ was $82.9 \mu \mathrm{M}$. By contrast, the trifluoromethyl group produced an increased inhibitory activity on Mtb. Compound 3n showed a MIC of $17.2 \mu \mathrm{M}$, which was slightly lower than that shown by the 31 structure. When the fluorine atom was used as a substitute attached to the 5-position of the indole ring, the resulting molecules did not show significant variations in their activity against the bacillus. The $1 H$-indoles $3 \mathbf{o}$ and $3 \mathbf{p}$ presented MIC values of $43.6 \mu \mathrm{M}$ and $35.8 \mu \mathrm{M}$, respectively. Finally, the chlorine atom was studied attached at the 5 -position of the indole ring in compounds $\mathbf{3 q}-\mathbf{t}$. As demonstrated above for molecule $\mathbf{3 a}$, the absence of substituents on the benzene ring significantly reduced antimycobacterial activity. Thus, the $1 H$-indole $3 q$ was inactive at the highest concentration tested $(>109.8 \mu \mathrm{M})$. Once again, the presence of the methoxy group produced an effective molecule, which was able to inhibit Mtb growth. The 3r structure exhibited an MIC of $19.4 \mu \mathrm{M}$, a value that ranks it among the most effective in the series examined. The fluorine-containing molecule 3 s showed a similar ability to inhibit the bacillus, with an MIC of $20.3 \mu \mathrm{M}$. Last but not least, the presence of the trifluoromethyl group on the benzene ring and the chlorine atom attached at the 5-position of the heterocycle led to the structure with the highest activity in the synthesized series. Compound 3t was able to inhibit Mtb growth with an MIC value of $8.4 \mu \mathrm{M}$. It is important to mention that trifluoromethyl group has unique physicochemical properties, increasing lipophilicity while reducing the reactivity of the compounds in metabolizing reactions. Particularly, greater lipophilicity may be related to the greater antimycobacterial activity of trifluoromethylated-1H-indoles (Scheme 1).

The most effective compounds against the H37Rv strain $(3 \mathbf{h}, 3 \mathbf{n}, 3 \mathbf{r}$, and $\mathbf{3 t})$ were evaluated against a well-characterized panel of clinical isolates described as multidrugresistant Mtb strains (Table 1). The PT2, PT12, and PT20 strains have been described as resistant to drugs such as isoniazid, rifampin, streptomycin, ethionamide, and rifabutine. In addition, PT12 and PT20 are also resistant to drugs such as pyrazinamide and ethambutol, and PT12 exhibits additional resistance to amikacin and capreomycin. Importantly, the genomes of these mycobacterial strains have been fully sequenced; therefore, genetic modifications related to resistance phenotypes are known [14]. Interestingly, the $1 H$-indoles 3h, 3n, 3r and 3t maintained the MIC value against the drug-resistant Mtb strains or were even more effective, with MIC values lower than those exhibited against the H37Rv strain. These findings demonstrate that this class of molecules does not share cross-resistance with some of the main drugs used for the clinical management of TB. Moreover, the results suggest that this chemical class may provide active compounds against drug-susceptible and drug-resistant Mtb strains, acting by distinct mechanisms of action when compared to first-line drugs.

Table 1. In vitro activity of the selected $1 H$-indoles against $M$. tuberculosis $H 37 R v$ and MDR strains and an evaluation of the viability of HepG2 and Vero cells.

\begin{tabular}{|c|c|c|c|c|c|c|}
\hline Compound & H37Rv ( $\mu \mathrm{M})$ & PT2 $(\mu \mathrm{M})$ & PT12 ( $\mu \mathrm{M})$ & PT20 ( $\mu \mathrm{M})$ & $\mathrm{CC}_{50}{ }^{\mathrm{a}}$ HepG2 $(\mu \mathrm{M})$ & $\mathrm{CC}_{50}{ }^{\text {a }}$ Vero $(\mu \mathrm{M})$ \\
\hline $3 h$ & 18.2 & 4.5 & 9.1 & 9.1 & $<30$ & $<30$ \\
\hline $3 n$ & 17.2 & 17.2 & 17.2 & 17.2 & $<30$ & $<30$ \\
\hline $3 r$ & 19.4 & 9.7 & 19.4 & 19.4 & $>30$ & $>30$ \\
\hline $3 t$ & 8.4 & 8.4 & 8.4 & 8.4 & $<30$ & $<30$ \\
\hline INH & 2.3 & 291.7 & 36.4 & 145.8 & - & - \\
\hline
\end{tabular}

${ }^{\text {a }}$ Concentration that inhibits 50\% of cellular viability determined by MTT and Neutral Red assays. INH, Isoniazid.

The viability of the HepG2 and Vero cells in the presence of the compounds was determined in order to evaluate the selectivity and provide preliminary evidence of the toxicity of the molecules. Cell viability was assessed at a mitochondrial (MTT) [15] and lysosomal (Neutral Red) [16] level after exposure to the $1 H$-indoles $\mathbf{3 h}, \mathbf{3 n}, \mathbf{3 r}$ and $\mathbf{3 t}$ for 
$72 \mathrm{~h}$ (Table 1). The results were expressed as the concentration capable of reducing cell viability by $50 \%\left(\mathrm{CC}_{50}\right) .1 \mathrm{H}$-Indoles $\mathbf{3 h}, \mathbf{3 n}$, and $\mathbf{3 t}$ inhibited the viability of both cell lines at concentrations less than $30 \mu \mathrm{M}$. This finding denotes that these molecules have a possible propensity for toxicity and a low selectivity, considering the relationship between mammalian cells (HepG2 and Vero) and mycobacterial (Mtb) cells. By contrast, compound $3 \mathrm{r}$ at $30 \mu \mathrm{M}$ concentration did not significantly affect the viability of either cell lineage. Based on these results, the $1 \mathrm{H}$-indole $3 \mathbf{r}$ was chosen for subsequent trials.

Additionally, the genotoxicity of compound $3 \mathrm{r}$ was studied, as cell viability results could indicate a certain degree of toxicity in the series of molecules evaluated. Therefore, the induction of DNA single and double-strand breaks and alkali-labile sites in HepG2 cells were evaluated using the alkaline comet assay [17]. The results demonstrated that compound $3 \mathbf{r}$ did not produce DNA damage at the evaluated concentrations (Figure 1). These results indicate a reasonable safety profile for $1 H$-indole $3 \mathrm{r}$ based on cytotoxic and genotoxic assessments.

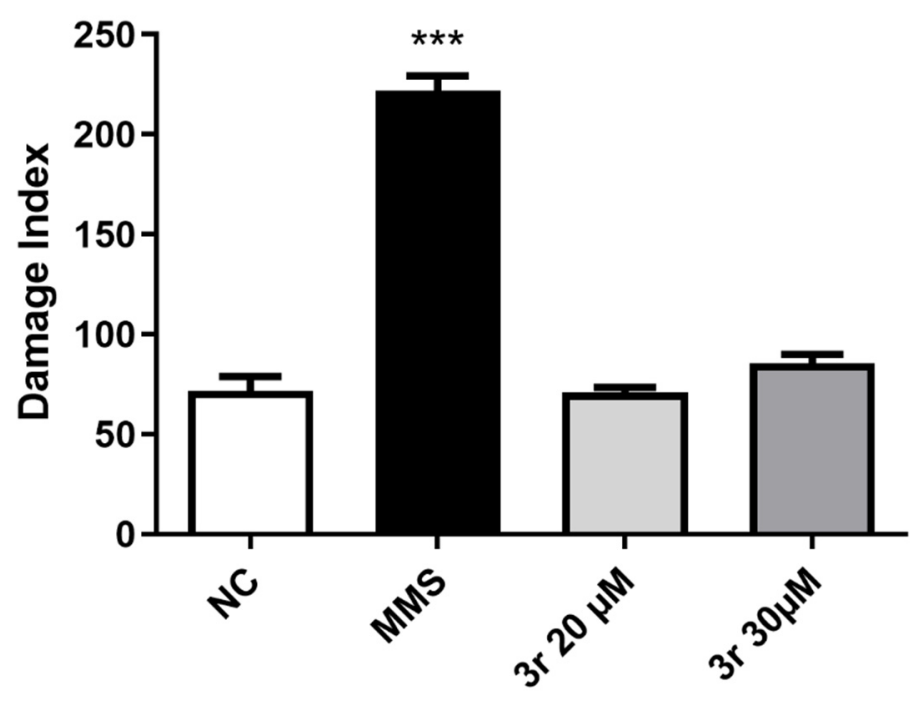

Figure 1. DNA damage index measured by alkaline comet assay in HepG2 cells incubated for $24 \mathrm{~h}$ with $3 \mathbf{r}$. NC = control vehicle group (0.5\% DMSO), MMS = methyl methanesulfonate, positive control group. Data are expressed as the mean \pm standard error from two independent experiments. Statistical analysis was performed by one-way analysis of variance followed by Dunnett's post-test. *** $p<0.001$.

The determination of the MIC of an antimicrobial drug is widely used as a marker of its effect. However, since the MIC value is obtained at a single time point, there is some information about other aspects of the antibiotic's effect that may be relevant, such as combinations of growth and kill rates, the persistent activity of the compound, and its effect over time. Thus, time-kill analysis of $1 H$-indole $3 \mathbf{r}$ was performed to assess the dynamics of the antimycobacterial activity [18-20] (Figure 2). Compound $3 \mathbf{r}$ showed timedependent kill kinetics at the highest evaluated concentrations. On day zero, the average $\mathrm{CFU} / \mathrm{mL}$ value was around 5 logs. The vehicle (DMSO) showed growth, with values around $8.8 \operatorname{logs}$ on day 21. Using a concentration of $0.5 \times$ MIC of compound $3 \mathbf{r}$, a regrowth of the culture was observed on day 21 (around $6.3 \operatorname{logs}$ ). However, this value was lower than that presented by the DMSO. $1 H$-Indole $3 \mathrm{r}$ at a concentration of $1.0 \times$ MIC value was able to maintain the culture in the range of 4.6 to 4.2 logs over the 21 days. Taken together, these results denote that concentrations of $0.5 \times$ MIC $(10 \mu \mathrm{M})$ and $1.0 \times \mathrm{MIC}(20 \mu \mathrm{M})$ of $3 r$ exhibited bacteriostatic effects over 21 days. In addition, the Minimum Bactericidal Concentration $(\mathrm{MBC})$ was $2 \times$ MIC $(40 \mu \mathrm{M})$, which reduced the culture count to around 2.3 logs on day 14 and below the detection limit on day 21 . It is noteworthy that there was no antimycobacterial time-dependent difference between $3 r$ concentrations of $2 \times$ and 
$4 \times$ MIC $(80 \mu \mathrm{M})$. These concentrations showed a slow reduction in viable cell count over time and a reduction of 3 logs on day 21. Finally, time-kill analysis showed that $1 H$-indole $3 \mathbf{r}$ presented a comparable dynamic behavior to the first-line drug rifampicin [20-22].

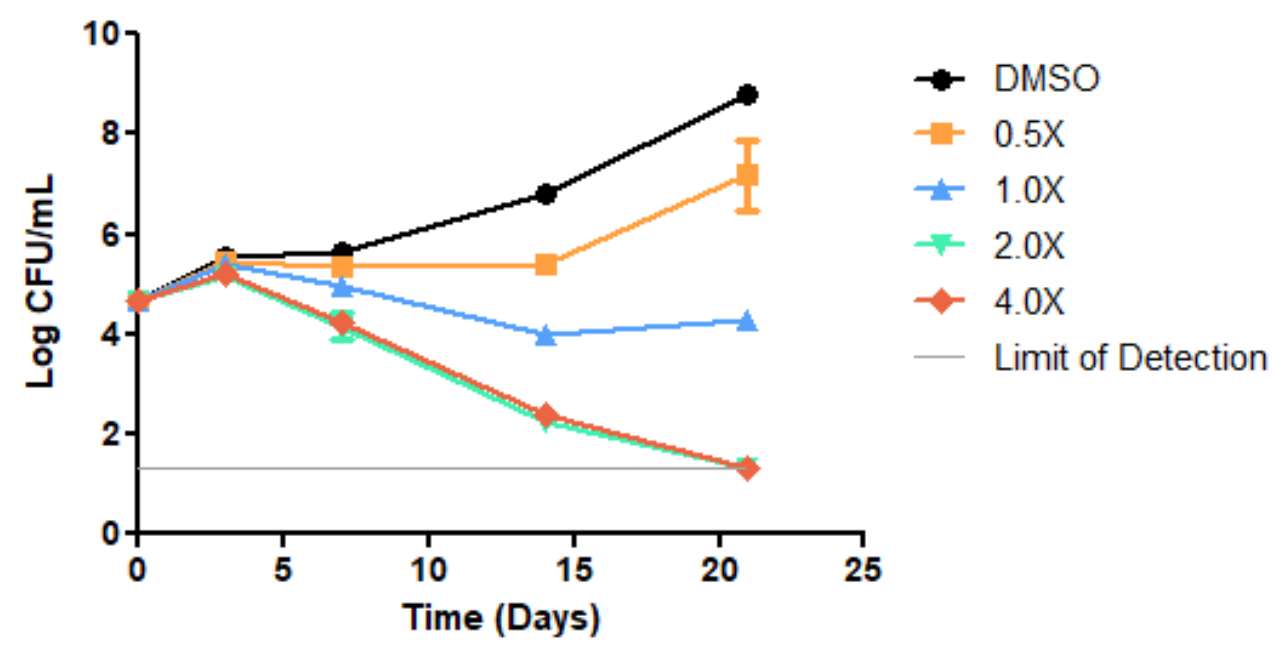

Figure 2. Time-kill curves of compound 3r against replicating Mycobacterium tuberculosis H37Rv. Kill kinetics were determined under standard aerobic conditions. Viability was monitored by determining $\mathrm{CFU} / \mathrm{mL}$. The lower limit of detection was $200 \mathrm{CFU} / \mathrm{mL}$ for undiluted samples on plates. Data represent the mean \pm standard deviation of biological triplicate measurements.

We used the pharmacodynamic model to explore the time-kill curve data from compound 3r. This model is characterized by four criteria: the maximum rate of bacterial growth in the absence of antimicrobial ( $\psi$ max), the minimum rate of bacterial growth in high concentrations of antimicrobial ( $\psi \mathrm{min})$, the Hill coefficient (к), and the pharmacodynamic MIC (zMIC) [23,24]. The time-kill curve data provides the bacterial growth rates by fitting a linear regression to the mean colony counts per day for every concentration of $1 \mathrm{H}$-indole $3 \mathbf{r}$ (Figure 3). The maximum growth rate in the absence of antimicrobial was $\psi \max =0.42$ days $^{-1}$. The minimum growth rate was $\psi \min =-0.94$ days $^{-1}$. The Hill coefficient Kwas 4.93, whereas the estimated zMIC was $18.73 \mu \mathrm{M}$. It is noteworthy that the zMIC value agreed with the experimental MIC $(19.40 \mu \mathrm{M})$. The Hill coefficient (к) describes how the kill rate changes with the change in concentration of the molecule tested around the MIC value. One can observe these changes on the graph as the steepness of the curve $[23,24]$. Some studies have suggested that a high or low Hill coefficient may be related to the concentration or time-dependent kill kinetics of antibiotics, with a tendency towards higher values for time dependent ones [24]. In addition, it was reported that a median Hill coefficient (к) value of three has been obtained for those drugs endowed with time-dependent kill kinetics [18]. Therefore, the pharmacodynamic model for $1 \mathrm{H}$-indole $3 \mathbf{r}$ indicated a strong time-dependent characteristic and a weak concentration-dependent antimycobacterial activity.

In summary, the synthesis and in vitro antimycobacterial activity of a new series of 3 -phenyl- $1 H$-indoles is shown herein. The highly regioselective synthetic procedure was performed using readily accessible reagents and reactants. In addition, most synthesized compounds showed activity against a drug-susceptible Mtb strain, and the top hit compounds were active against MDR strains without cross-resistance with first-line drugs. Interestingly, one of the compounds was also devoid of apparent toxicity and genotoxicity to mammalian cells. Time-kill and pharmacodynamic model analyses demonstrated that this molecule has bactericidal activity at concentrations close to the MIC $(2 \times \mathrm{MIC})$, with a strongly time-dependent behavior. The data presented suggest that this class of molecules may provide candidates for the development of new anti-TB drugs. Hit to lead optimization is underway, and these data will be presented in due course. 


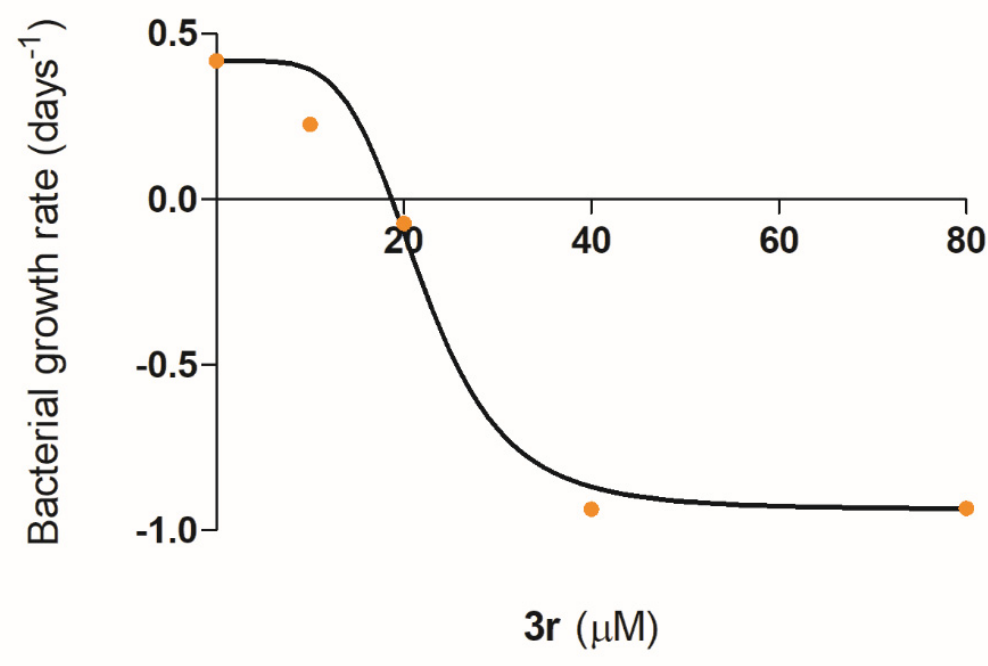

Figure 3. Pharmacodynamic model fitted to estimated growth rates. The points indicate the estimated bacterial growth rates at different concentrations of compound 3r. The solid line shows the model with the calculated growth rates.

\section{Experimental}

\subsection{Chemistry}

Commercially available reactants and solvents were obtained from commercial suppliers and were used without additional purification. The progress of the reaction was monitored using thin-layer chromatography (TLC, Kenilworth, NJ, USA) with Merck TLC Silica gel 60 F254. The melting points were measured using a Microquímica MQAPF-302 apparatus. ${ }^{1} \mathrm{H}$ and ${ }^{13} \mathrm{C}$ NMR spectra were acquired on an Avance III HD Bruker spectrometer (Bruker Corporation, Fällanden, Switzerland). Chemical shifts $(\delta)$ were expressed in parts per million (ppm) relative to $\mathrm{CDCl}_{3}$, which was used as the solvent, and to TMS, which was used as an internal standard. High-resolution mass spectra (HRMS) were obtained for all compounds on an LTQ Orbitrap Discovery mass spectrometer (Thermo Fisher Scientific, Bremen, Germany). The analyses were performed through the direct infusion of the sample in $\mathrm{MeCN} / \mathrm{H}_{2} \mathrm{O}$ (1:1) with $0.1 \%$ formic acid, or in $\mathrm{MeOH} / \mathrm{MeCN}(1: 1)$ with $0.025 \%$ ammonium hydroxide in a positive-ion or negative-ion mode, respectively, using electrospray ionization (ESI). For elemental composition, calculations were performed using the specific tool included in the Qual Browser module of the Xcalibur software. Compound purity was determined using an Äkta HPLC system (GE Healthcare ${ }^{\circledR}$ Life Sciences, Chicago, IL, USA) equipped with a binary pump, manual injector, and UV detector. Unicorn 5.31 software (Build 743) was used for data acquisition and processing. The HPLC conditions were as follows: RP column, $5 \mu \mathrm{m}$ Nucleodur C-18 $(250 \times 4.6 \mathrm{~mm})$; flow rate, $1.5 \mathrm{~mL} / \mathrm{min}$; UV detection, $254 \mathrm{~nm} ; 100 \%$ water $(0.1 \%$ acetic acid) was maintained from 0 to $7 \mathrm{~min}$, followed by a linear gradient from $100 \%$ water $(0.1 \%$ acetic acid) to $90 \%$ acetonitrile/methanol (1:1, $v / v)$ from 7 to $15 \mathrm{~min}(15-30 \mathrm{~min})$ and subsequently returned to $100 \%$ water $(0.1 \%$ acetic acid) in $5 \mathrm{~min}(30-35 \mathrm{~min})$ and maintained for an additional $10 \mathrm{~min}$ ( $35-45 \mathrm{~min})$. All the evaluated compounds were $\geq 92 \%$ pure.

\subsection{General Procedure for the Synthesis of 3-Phenyl-1H-indoles (3a-t)}

In a screw-cap vial under air, a mixture of $\mathrm{Pd}(\mathrm{OAc})_{2}(11.3 \mathrm{mg}, 0.05 \mathrm{mmol}, 5 \mathrm{~mol} \%)$, dppm (19.2 mg, $0.05 \mathrm{mmol}, 5 \mathrm{~mol} \%), \mathrm{LiOH} \cdot \mathrm{H}_{2} \mathrm{O}(126 \mathrm{mg}, 3.00 \mathrm{mmol})$, proper aryl-halide $(1.20 \mathrm{mmol})$, and proper indole $(1.0 \mathrm{mmol})$ in degassed $\mathrm{H}_{2} \mathrm{O}(2 \mathrm{~mL})$ was vigorously stirred at $110{ }^{\circ} \mathrm{C}$. After $18 \mathrm{~h}$, the reaction mixture was cooled to room temperature and partitioned between $1 \mathrm{M} \mathrm{HCl}(20 \mathrm{~mL})$ and ethyl acetate $(20 \mathrm{~mL})$. The layers were separated, and the aqueous layer was further extracted with $4 \times 20 \mathrm{~mL}$ EtOAc. Combined organic layers were 
dried over $\mathrm{MgSO}_{4}$, filtered, and concentrated under reduced pressure. Purification of the residue by column chromatography using a mixture of hexanes/EtOAc as eluent afforded the desired product.

3-Phenyl-1H-indole (3a) [13]: Flash column chromatography on a silica gel (hexanes/ethyl acetate, $0 \rightarrow 90 / 10$ ) yielded the product as a white solid: $77 \%$ yield; $\mathrm{mp} 82-85^{\circ} \mathrm{C}$. ${ }^{1} \mathrm{H}-\mathrm{NMR}$ $\left(400 \mathrm{MHz}, \mathrm{CDCl}_{3}\right) \delta: 8.20(1 \mathrm{H}, \mathrm{bs}), 7.95(1 \mathrm{H}, \mathrm{d}, J=8.0 \mathrm{~Hz}), 7.67(2 \mathrm{H}, \mathrm{dt}, J=8.0,1.5 \mathrm{~Hz})$, 7.48-7.39 $(3 \mathrm{H}, \mathrm{m}), 7.36(1 \mathrm{H}, \mathrm{d}, J=2.5 \mathrm{~Hz}), 7.32-7.16(3 \mathrm{H}, \mathrm{m}) .{ }^{13} \mathrm{C}-\mathrm{NMR}\left(101 \mathrm{MHz}, \mathrm{CDCl}_{3}\right) \delta$ : $136.7,135.6,128.7$ (2C), 127.5 (2C), 125.9, 125.8, 122.4, 121.7, 120.3, 119.8, 118.4, 111.4. HRMS (ESI): $m / z$ calc. for $\mathrm{C}_{14} \mathrm{H}_{10} \mathrm{~N}[\mathrm{M}-\mathrm{H}]^{-}:$: 192.0819; obt.: 192.0834 .

3 -(p-Tolyl)-1H-indole (3b) $[25,26]$ : Flash column chromatography on a silica gel (petroleum ether/ethyl acetate, $0 \rightarrow 95 / 5$ ) yielded the product as a pale yellow solid: $30 \%$ yield; $\mathrm{mp}$ $73-75{ }^{\circ} \mathrm{C} .{ }^{1} \mathrm{H}-\mathrm{NMR}\left(400 \mathrm{MHz}, \mathrm{CDCl}_{3}\right) \delta: 7.91(1 \mathrm{H}, \mathrm{d}, J=7.5 \mathrm{~Hz}), 7.78(1 \mathrm{H}, \mathrm{bs}), 7.52(2 \mathrm{H}, \mathrm{d}$, $J=8.1 \mathrm{~Hz}), 7.18-7.13(5 \mathrm{H}, \mathrm{m}), 7.09(1 \mathrm{H}, \mathrm{d}, J=2.5 \mathrm{~Hz}), 2.36(3 \mathrm{H}, \mathrm{s}) .{ }^{13} \mathrm{C}-\mathrm{NMR}(101 \mathrm{MHz}$, $\left.\mathrm{CDCl}_{3}\right) \delta: 136.8,135.7,132.8,129.7(2 \mathrm{C}), 127.5$ (2C), 125.9, 122.4, 121.8, 120.4, 119.9, 118.2, 111.6, 21.3. HRMS (ESI): $m / z$ calc. for $\mathrm{C}_{15} \mathrm{H}_{12} \mathrm{~N}[\mathrm{M}-\mathrm{H}]^{-}:$: 206.0975; obt.: 206.0989 .

3-(4-Methoxyphenyl)-1H-indole (3c) [13]: Flash column chromatography on a silica gel (petroleum ether/ethyl acetate, $0 \rightarrow 95 / 5)$ yielded the product as a pale-yellow solid: $68 \%$ yield; mp $126-129{ }^{\circ} \mathrm{C} .{ }^{1} \mathrm{H}-\mathrm{NMR}\left(400 \mathrm{MHz}, \mathrm{CDCl}_{3}\right) \delta: 8.18(1 \mathrm{H}, \mathrm{bs}), 7.95(1 \mathrm{H}, \mathrm{d}$, $J=7.8 \mathrm{~Hz}), 7.65-7.62(2 \mathrm{H}, \mathrm{m}), 7.44(1 \mathrm{H}, \mathrm{d}, J=7.9 \mathrm{~Hz}), 7.31-7.21(3 \mathrm{H}, \mathrm{m}), 7.07-7.04(2 \mathrm{H}, \mathrm{m})$, $3.91(3 \mathrm{H}, \mathrm{s}) .{ }^{13} \mathrm{C}-\mathrm{NMR}\left(101 \mathrm{MHz}, \mathrm{CDCl}_{3}\right) \delta: 158.2,136.6,128.7(2 \mathrm{C}), 128.6,128.2,125.9$, $122.3,121.2,120.2,119.8,118.1,114.3,111.4,55.4$. HRMS (ESI): $\mathrm{m} / z$ calc. for $\mathrm{C}_{15} \mathrm{H}_{12} \mathrm{NO}[\mathrm{M}$ $-\mathrm{H}]^{-}:$222.0924; obt.: 222.0945.

3-(4-Fluorophenyl)-1H-indole (3d) [27]: Flash column chromatography on a silica gel (hexanes/ethyl acetate, $0 \rightarrow 90 / 10$ ) yielded the product as a light yellow solid: $35 \%$ yield; $\mathrm{mp}$ 96-99 ${ }^{\circ} \mathrm{C} .{ }^{1} \mathrm{H}-\mathrm{NMR}\left(400 \mathrm{MHz}, \mathrm{CDCl}_{3}\right) \delta: 8.08(1 \mathrm{H}, \mathrm{bs}), 7.89-7.83(1 \mathrm{H}, \mathrm{m}), 7.60-7.56(2 \mathrm{H}$, m), 7.39-7.35 (1H, m), 7.27-7.17 (3H, m), 7.15-7.09 (2H, m). ${ }^{13} \mathrm{C}-\mathrm{NMR}\left(101 \mathrm{MHz}, \mathrm{CDCl}_{3}\right)$ $\delta: 161.5(\mathrm{~d}, J=244.5 \mathrm{~Hz}), 136.5,131.5(\mathrm{~d}, J=3.2 \mathrm{~Hz}), 128.9,128.8,125.7,122.5,121.6,120.4$, $119.5,117.4,115.6(\mathrm{~d}, 2 \mathrm{C}, J=21.3 \mathrm{~Hz}), 111.4$. HRMS (ESI): $m / z$ calc. for $\mathrm{C}_{14} \mathrm{H}_{9} \mathrm{FN}[\mathrm{M}-\mathrm{H}]^{-}$: 210.0725; obt.: 210.0758 .

3-(4-(Trifluoromethyl)phenyl)-1H-indole (3e) [28]: Flash column chromatography on a silica gel (hexanes/ethyl acetate, $95 / 5 \rightarrow 80 / 10$ ) yielded the product as a light yellow solid: $69 \%$ yield; mp 129-132 ${ }^{\circ} \mathrm{C} .{ }^{1} \mathrm{H}-\mathrm{NMR}\left(400 \mathrm{MHz}, \mathrm{CDCl}_{3}\right) \delta: 8.32(1 \mathrm{H}, \mathrm{bs}), 7.98(1 \mathrm{H}, \mathrm{d}, J=7.9 \mathrm{~Hz})$, $7.82(2 \mathrm{H}, \mathrm{d}, J=8.1 \mathrm{~Hz}), 7.73(2 \mathrm{H}, \mathrm{d}, J=8.4 \mathrm{~Hz}), 7.48(1 \mathrm{H}, \mathrm{d}, J=7.7 \mathrm{~Hz}), 7.44(1 \mathrm{H}, \mathrm{d}$, $J=2.6 \mathrm{~Hz}), 7.35-7.26(2 \mathrm{H}, \mathrm{m}) .{ }^{13} \mathrm{C}-\mathrm{NMR}\left(101 \mathrm{MHz}^{\mathrm{C}} \mathrm{CDCl}_{3}\right) \delta: 139.4,136.8,127.8(2 \mathrm{C}), 127.6$ $(\mathrm{q}, J=33.6 \mathrm{~Hz}), 127.3,125.7(\mathrm{q}, J=3.8 \mathrm{~Hz}), 125.5,124.5(\mathrm{q}, J=271.6 \mathrm{~Hz}), 122.8,122.6,120.9$, 119.6, 117.1, 111.6. HRMS (ESI): $m / z$ calc. for $\mathrm{C}_{15} \mathrm{H}_{9} \mathrm{~F}_{3} \mathrm{~N}[\mathrm{M}-\mathrm{H}]^{-}: 260.0693$; obt.: 260.0725 . 3-(4-Methoxyphenyl)-2-methyl-1H-indole (3f): Flash column chromatography on a silica gel (hexanes/ethyl acetate, $90 / 10 \rightarrow 80 / 20$ ) yielded the product as a brown oil: $10 \%$ yield. ${ }^{1} \mathrm{H}-\mathrm{NMR}\left(400 \mathrm{MHz}, \mathrm{CDCl}_{3}\right) \delta: 7.80(1 \mathrm{H}, \mathrm{s}), 7.54(1 \mathrm{H}, \mathrm{d}, J=7.8 \mathrm{~Hz}), 7.38-7.31(2 \mathrm{H}, \mathrm{m})$, $7.22(1 \mathrm{H}, \mathrm{dd}, J=8.0,1.1 \mathrm{~Hz}), 7.11-6.99(2 \mathrm{H}, \mathrm{m}), 6.96-6.91(2 \mathrm{H}, \mathrm{m}), 3.79(3 \mathrm{H}, \mathrm{d}, J=0.7 \mathrm{~Hz})$, $2.38(3 \mathrm{H}, \mathrm{s}) .{ }^{13} \mathrm{C}-\mathrm{NMR}\left(101 \mathrm{MHz}, \mathrm{CDCl}_{3}\right) \delta: 157.9,135.2,131.0,130.5,130.4,128.0,127.8$, $121.4,119.8,118.8,118.7,114.0,113.9,110.2,55.4,12.4$. HRMS (ESI): $m / z$ calc. for $\mathrm{C}_{16} \mathrm{H}_{14} \mathrm{NO}$ $[\mathrm{M}-\mathrm{H}]^{-}:$236.1087; obt.: 236.1070 .

3-(4-Fluorophenyl)-2-methyl-1H-indole (3g): Flash column chromatography on a silica gel (hexanes/ethyl acetate, $90 / 10 \rightarrow 80 / 20$ ) yielded the product as a brown solid: $10 \%$ yield; mp 95-98 ${ }^{\circ} \mathrm{C} .{ }^{1} \mathrm{H}-\mathrm{NMR}\left(400 \mathrm{MHz}, \mathrm{CDCl}_{3}\right)$ 8: $7.87(1 \mathrm{H}, \mathrm{s}), 7.54-7.49(1 \mathrm{H}, \mathrm{m}), 7.40-7.34(2 \mathrm{H}$, m), 7.28-7.21 (1H, m), 7.13-7.01 (4H, m), $2.39(3 \mathrm{H}, \mathrm{s}) .{ }^{13} \mathrm{C}-\mathrm{NMR}\left(101 \mathrm{MHz}, \mathrm{CDCl}_{3}\right) \delta: 161.3$ $(\mathrm{d}, J=244.6 \mathrm{~Hz}), 135.1,131.3(2 \mathrm{C}), 130.8(2 \mathrm{C}), 127.8,121.6,120.0,118.5(\mathrm{~d}, J=9.0 \mathrm{~Hz}), 115.4$ $(\mathrm{d}, J=7.5 \mathrm{~Hz}), 115.2(\mathrm{~d}, J=7.4 \mathrm{~Hz}), 113.6,110.3,12.4$. HRMS (ESI): $m / z$ calc. for $\mathrm{C}_{15} \mathrm{H}_{11} \mathrm{NF}$ $[\mathrm{M}-\mathrm{H}]^{-}: 224.0887$; obt.: 224.0870 .

3-(4-(Trifluoromethyl)phenyl)-2-methyl-1H-indole (3h): Flash column chromatography on a silica gel (hexanes/ethyl acetate, $90 / 10 \rightarrow 80 / 20$ ) yielded the product as a pale yellow solid: $16 \%$ yield; mp $128-131{ }^{\circ} \mathrm{C} .{ }^{1} \mathrm{H}-\mathrm{NMR}\left(400 \mathrm{MHz}, \mathrm{CDCl}_{3}\right) \delta: 7.90(1 \mathrm{H}, \mathrm{s}), 7.65-7.60$ 
(2H, m), 7.58-7.50 (3H, m), 7.27-7.22 (1H, m), 7.14-7.03 (2H, m), $2.41(3 \mathrm{H}, \mathrm{s}) .{ }^{13} \mathrm{C}-\mathrm{NMR}$ $\left(101 \mathrm{MHz}, \mathrm{CDCl}_{3}\right) \delta: 139.4,135.2,132.2,129.4,127.7(\mathrm{q}, 2 \mathrm{C}, J=32.2 \mathrm{~Hz}), 127.4,125.4(2 \mathrm{C})$, $124.5(\mathrm{q}, J=271.8 \mathrm{~Hz}), 121.9,120.6,118.5(\mathrm{q}, J=8.5 \mathrm{~Hz}), 113.4,110.5,12.5$. HRMS (ESI): $\mathrm{m} / \mathrm{z}$ calc. for $\mathrm{C}_{16} \mathrm{H}_{11} \mathrm{NF}_{3}[\mathrm{M}-\mathrm{H}]^{-}:$274.0858; obt.: 274.0838 .

5-Methyl-3-(4-fluorophenyl)-1H-indole (3i) [29]: Flash column chromatography on a silica gel (hexanes/ethyl acetate, $0 \rightarrow 90 / 10$ ) yielded the product as a light yellow solid: $20 \%$ yield; mp 121-123 ${ }^{\circ} \mathrm{C} .{ }^{1} \mathrm{H}-\mathrm{NMR}\left(400 \mathrm{MHz}, \mathrm{CDCl}_{3}\right) \delta: 8.12(1 \mathrm{H}, \mathrm{s}), 7.64(1 \mathrm{H}, \mathrm{s}), 7.61-7.54(2 \mathrm{H}, \mathrm{m})$, $7.29(1 \mathrm{H}, \mathrm{d}, J=8.3 \mathrm{~Hz}), 7.23(1 \mathrm{H}, \mathrm{d}, J=2.5 \mathrm{~Hz}), 7.15-7.05(3 \mathrm{H}, \mathrm{m}), 2.47(3 \mathrm{H}, \mathrm{s}) .{ }^{13} \mathrm{C}-\mathrm{NMR}$ $\left(101 \mathrm{MHz}, \mathrm{CDCl}_{3}\right) \delta: 161.4(\mathrm{~d}, J=244.3 \mathrm{~Hz}), 134.9,131.7(\mathrm{~d}, J=3.3 \mathrm{~Hz}), 129.7,128.9,128.8$, $125.9,124.1,121.7(2 \mathrm{C}), 119.1,116.9,115.5(\mathrm{~d}, J=21.3 \mathrm{~Hz}), 111.1,21.6$. HRMS (ESI): $\mathrm{m} / \mathrm{z}$ calc. for $\mathrm{C}_{15} \mathrm{H}_{11} \mathrm{NF}[\mathrm{M}-\mathrm{H}]^{-}$: 224.0884; obt.: 224.0870.

5-Methyl-3-(4-(trifluoromethyl)phenyl)-1H-indole (3j) [30]: Flash column chromatography on a silica gel (hexanes/ethyl acetate, $0 \rightarrow 90 / 10$ ) yielded the product as a light yellow oil: $16 \%$ yield. ${ }^{1} \mathrm{H}-\mathrm{NMR}\left(400 \mathrm{MHz}, \mathrm{CDCl}_{3}\right) \delta: 8.32(1 \mathrm{H}, \mathrm{s}), 7.75(2 \mathrm{H}, \mathrm{dt}, J=7.9,0.8 \mathrm{~Hz}), 7.69(3 \mathrm{H}, \mathrm{ddt}$, $J=8.8,7.3,0.8 \mathrm{~Hz}), 7.37(1 \mathrm{H}, \mathrm{d}, J=2.6 \mathrm{~Hz}), 7.33(1 \mathrm{H}, \mathrm{dd}, J=8.3,0.7 \mathrm{~Hz}), 7.10(1 \mathrm{H}, \mathrm{dd}, J=8.3$, $1.6 \mathrm{~Hz}), 2.49(3 \mathrm{H}, \mathrm{s}) .{ }^{13} \mathrm{C}-\mathrm{NMR}\left(101 \mathrm{MHz}, \mathrm{CDCl}_{3}\right) \delta: 139.5(\mathrm{~d}, J=1.4 \mathrm{~Hz}), 135.1,130.1,127.6$ $(\mathrm{q}, 2 \mathrm{C}, J=32.2 \mathrm{~Hz}), 127.3(2 \mathrm{C}), 125.6(\mathrm{q}, 2 \mathrm{C}, J=3.9 \mathrm{~Hz}), 124.5(\mathrm{q}, J=271.7 \mathrm{~Hz}), 124.4,122.7$, 119.1, 116.6, 111.3, 21.6. HRMS (ESI): $m / z$ calc. for $\mathrm{C}_{16} \mathrm{H}_{11} \mathrm{NF}_{3}[\mathrm{M}-\mathrm{H}]^{-}: 274.0854$; obt.: 274.0838 .

5-Methoxy-3-(p-tolyl)-1H-indole (3k) [26]: Flash column chromatography on a silica gel (hexanes/ethyl acetate, $0 \rightarrow 90 / 10$ ) yielded the product as a pale yellow solid: $58 \%$ yield; mp 141-144 ${ }^{\circ} \mathrm{C} .{ }^{1} \mathrm{H}-\mathrm{NMR}\left(400 \mathrm{MHz}, \mathrm{CDCl}_{3}\right) \delta: 8.05(1 \mathrm{H}, \mathrm{bs}), 7.53(2 \mathrm{H}, \mathrm{d}, J=8.0 \mathrm{~Hz}), 7.36$ $(1 \mathrm{H}, \mathrm{d}, J=2.4 \mathrm{~Hz}), 7.30-7.23(4 \mathrm{H}, \mathrm{m}), 6.90(1 \mathrm{H}, \mathrm{dd}, J=8.8,2.4 \mathrm{~Hz}), 3.85(3 \mathrm{H}, \mathrm{s}), 2.40(3 \mathrm{H}$, s). ${ }^{13} \mathrm{C}-\mathrm{NMR}\left(101 \mathrm{MHz}, \mathrm{CDCl}_{3}\right) \delta: 154.7,135.5,132.7,131.8,129.4$ (2C), 127.3 (2C), 126.3, $122.3,118.1,112.6,112.0,101.8,56.0,21.1$. HRMS (ESI): $m / z$ calc. for $\mathrm{C}_{16} \mathrm{H}_{16} \mathrm{NO}[\mathrm{M}+\mathrm{H}]^{+}$: 238.1226; obt.: 238.1251.

5-Methoxy-3-(4-methoxyphenyl)-1H-indole (31) [27]: Flash column chromatography on a silica gel (hexanes/ethyl acetate, $0 \rightarrow 90 / 10$ ) yielded the product as a pale yellow solid: $26 \%$ yield, $\mathrm{mp} 72-75^{\circ} \mathrm{C} .{ }^{1} \mathrm{H}-\mathrm{NMR}\left(400 \mathrm{MHz}, \mathrm{CDCl}_{3}\right) \delta: 8.13(1 \mathrm{H}, \mathrm{s}), 7.60-7.52(2 \mathrm{H}, \mathrm{m}), 7.35-7.28$ $(3 \mathrm{H}, \mathrm{m}), 7.03-6.98(2 \mathrm{H}, \mathrm{m}), 6.91(1 \mathrm{H}, \mathrm{dd}, J=8.8,2.5 \mathrm{~Hz}), 3.86(6 \mathrm{H}, \mathrm{s}) .{ }^{13} \mathrm{C}-\mathrm{NMR}(101 \mathrm{MHz}$, $\left.\mathrm{CDCl}_{3}\right)$ ) $154.7(2 \mathrm{C}), 131.8,128.6(3 \mathrm{C}), 122.0(3 \mathrm{C}), 114.3(2 \mathrm{C}), 112.6,112.0,101.6,56.0,55.4$. HRMS (ESI): $m / z$ calc. for $\mathrm{C}_{16} \mathrm{H}_{16} \mathrm{NO}_{2}[\mathrm{M}+\mathrm{H}]^{+}:$254.1176; obt.: 254.1177 .

5-Methoxy-3-(4-fluorophenyl)-1H-indole (3m): Flash column chromatography on a silica gel (hexanes/ethyl acetate, 95/5 $\rightarrow$ 90/10) yielded the product as a yellow oil that solidified upon cooling: $53 \%$ yield. ${ }^{1} \mathrm{H}-\mathrm{NMR}\left(400 \mathrm{MHz}, \mathrm{CDCl}_{3}\right) \delta: 8.01(1 \mathrm{H}, \mathrm{s}), 7.49-7.42(2 \mathrm{H}, \mathrm{m})$, $7.21(1 \mathrm{H}, \mathrm{dd}, J=2.4,0.7 \mathrm{~Hz}), 7.15(1 \mathrm{H}, \mathrm{dd}, J=8.8,0.6 \mathrm{~Hz}), 7.12-7.09(1 \mathrm{H}, \mathrm{m}), 7.07-6.99(2 \mathrm{H}$, m), $6.82(1 \mathrm{H}, \mathrm{ddd}, J=8.8,2.4,0.5 \mathrm{~Hz}), 3.75(3 \mathrm{H}, \mathrm{s}) .{ }^{13} \mathrm{C}-\mathrm{NMR}\left(101 \mathrm{MHz}, \mathrm{CDCl}_{3}\right) \delta: 161.3(\mathrm{~d}$, $J=244.4 \mathrm{~Hz}), 154.7,131.7,128.8,128.6,126.0,122.5,122.4,117.0,115.6(\mathrm{~d}, 2 \mathrm{C}, J=21.2 \mathrm{~Hz})$, 112.6, 112.2, 101.3, 56.0. HRMS (ESI): $m / z$ calc. for $\mathrm{C}_{15} \mathrm{H}_{11} \mathrm{NOF}[\mathrm{M}-\mathrm{H}]^{-}: 240.0832$; obt.: 240.0819 .

5-Methoxy-3-(4-(trifluoromethyl)phenyl)-1H-indole (3n): Flash column chromatography on a silica gel (hexanes/ethyl acetate, $0 \rightarrow 90 / 10$ ) yielded the product as a dark yellow solid: $43 \%$ yield; mp $90-93{ }^{\circ} \mathrm{C} .{ }^{1} \mathrm{H}-\mathrm{NMR}\left(400 \mathrm{MHz}, \mathrm{CDCl}_{3}\right) \delta: 8.23(1 \mathrm{H}, \mathrm{bs}), 7.74(2 \mathrm{H}, \mathrm{d}$, $J=8.6 \mathrm{~Hz}), 7.68(2 \mathrm{H}, \mathrm{d}, J=8.4 \mathrm{~Hz}), 7.37(2 \mathrm{H}, \mathrm{q}, J=4.3 \mathrm{~Hz}), 7.33(1 \mathrm{H}, \mathrm{d}, J=8.8 \mathrm{~Hz}), 6.94(1 \mathrm{H}$, $\mathrm{q}, J=3.7 \mathrm{~Hz}), 3.87(1 \mathrm{H}, \mathrm{s}) .{ }^{13} \mathrm{C}-\mathrm{NMR}\left(101 \mathrm{MHz}, \mathrm{CDCl}_{3}\right) \delta: 155.1,139.5(\mathrm{~d}, J=1.2 \mathrm{~Hz}), 131.9$, $127.8(\mathrm{q}, 2 \mathrm{C}, J=33.0 \mathrm{~Hz}), 127.2,125.9,125.7(\mathrm{q}, 2 \mathrm{C}, J=3.8 \mathrm{~Hz}), 124.5(\mathrm{q}, J=270.7 \mathrm{~Hz}), 123.3$, $116.9,113.0,112.3,101.6,56.0$. HRMS (ESI): $\mathrm{m} / z$ calc. for $\mathrm{C}_{16} \mathrm{H}_{11} \mathrm{NOF}_{3}[\mathrm{M}-\mathrm{H}]^{-}: 290.0798$; obt.: 290.0787.

5-Fluoro-3-(4-fluorophenyl)-1H-indole (3o) [29]: The general procedure was followed although the temperature was $90^{\circ} \mathrm{C}$. Flash column chromatography on a silica gel (hexanes/ethyl acetate, $90 / 10 \rightarrow 70 / 30)$ yielded the product as a brown oil: $10 \%$ yield. ${ }^{1} \mathrm{H}-\mathrm{NMR}(400 \mathrm{MHz}$, $\left.\mathrm{CDCl}_{3}\right) \delta: 8.28(1 \mathrm{H}, \mathrm{s}), 7.60-7.50(2 \mathrm{H}, \mathrm{m}), 7.50(1 \mathrm{H}, \mathrm{dd}, J=9.9,2.5 \mathrm{~Hz}), 7.33(2 \mathrm{H}, \mathrm{dd}, J=8.6$, $3.7 \mathrm{~Hz}), 7.19-7.08(2 \mathrm{H}, \mathrm{m}), 7.00(1 \mathrm{H}, \mathrm{td}, J=9.0,2.5 \mathrm{~Hz}) .{ }^{13} \mathrm{C}-\mathrm{NMR}\left(101 \mathrm{MHz}, \mathrm{CDCl}_{3}\right) \delta$ : 
$161.6(\mathrm{~d}, J=245.0 \mathrm{~Hz}), 158.5(\mathrm{~d}, J=235.1 \mathrm{~Hz}), 133.1,131.1(\mathrm{~d}, J=3.3 \mathrm{~Hz}), 128.8(\mathrm{~d}, 2 \mathrm{C}$, $J=7.8 \mathrm{~Hz}), 126.1(\mathrm{~d}, J=9.9 \mathrm{~Hz}), 123.3,117.7(\mathrm{~d}, J=4.6 \mathrm{~Hz}), 115.7(\mathrm{~d}, 2 \mathrm{C}, J=21.5 \mathrm{~Hz}), 112.1$ $(\mathrm{d}, J=9.7 \mathrm{~Hz}), 110.9(\mathrm{~d}, J=26.4 \mathrm{~Hz}), 104.5(\mathrm{~d}, J=24.2 \mathrm{~Hz})$. HRMS (ESI): $m / z$ calc. for $\mathrm{C}_{14} \mathrm{H}_{8} \mathrm{~F}_{2} \mathrm{~N}[\mathrm{M}-\mathrm{H}]^{-}: 228.0630$; obt.: 228.0652.

5-Fluoro-3-(4-(trifluoromethyl)phenyl)-1H-indole (3p): The general procedure was followed although the reaction temperature was $90{ }^{\circ} \mathrm{C}$. Flash column chromatography on a silica gel (hexanes/ethyl acetate, 95/5 $\rightarrow$ 90/10) yielded the product as a brown oil: 35\% yield ${ }^{1} \mathrm{H}-\mathrm{NMR}\left(400 \mathrm{MHz}, \mathrm{CDCl}_{3}\right) \delta: 8.47(1 \mathrm{H}, \mathrm{s}), 7.73-7.63(4 \mathrm{H}, \mathrm{m}), 7.55(1 \mathrm{H}, \mathrm{dd}, J=9.9,2.5 \mathrm{~Hz})$, $7.44(1 \mathrm{H}, \mathrm{d}, J=2.7 \mathrm{~Hz}), 7.34(1 \mathrm{H}, \mathrm{dd}, J=8.9,4.4 \mathrm{~Hz}), 7.01(1 \mathrm{H}, \mathrm{td}, J=9.0,2.5 \mathrm{~Hz}) .{ }^{13} \mathrm{C}-\mathrm{NMR}$ $\left(101 \mathrm{MHz}, \mathrm{CDCl}_{3}\right) \delta: 158.6(\mathrm{~d}, J=235.6 \mathrm{~Hz}), 138.9(\mathrm{~d}, J=1.5 \mathrm{~Hz}), 133.3,127.9(\mathrm{q}, J=32.4 \mathrm{~Hz})$, $127.1(2 \mathrm{C}), 125.8(\mathrm{q}, J=3.8 \mathrm{~Hz}), 124.2,123.1,121.2(\mathrm{q}, J=170.9 \mathrm{~Hz}), 117.2(\mathrm{~d}, J=4.7 \mathrm{~Hz})$, $112.3(\mathrm{~d}, J=9.7 \mathrm{~Hz}), 111.2(\mathrm{~d}, J=26.4 \mathrm{~Hz}), 104.6(\mathrm{~d}, J=24.3 \mathrm{~Hz})$. HRMS (ESI): $m / z$ calc. for $\mathrm{C}_{15} \mathrm{H}_{8} \mathrm{NF}_{4}[\mathrm{M}-\mathrm{H}]^{-}: 278.0611$; obt.: 278.0587 .

5-Chloro-3-phenyl-1H-indole (3q) [31]: Flash column chromatography on a silica gel (hexanes /ethyl acetate, $0 \rightarrow 93 / 7$ ) yielded the product as a light yellow solid: $67 \%$ yield; mp 87-90 ${ }^{\circ} \mathrm{C} .{ }^{1} \mathrm{H}-\mathrm{NMR}\left(400 \mathrm{MHz}, \mathrm{CDCl}_{3}\right) \delta: 8.24(1 \mathrm{H}, \mathrm{bs}), 7.94(1 \mathrm{H}, \mathrm{d}, J=1.5 \mathrm{~Hz}), 7.67-7.65$ $(2 \mathrm{H}, \mathrm{m}), 7.50(2 \mathrm{H}, \mathrm{t}, J=7.7 \mathrm{~Hz}), 7.40-7.31(3 \mathrm{H}, \mathrm{m}), 7.24(1 \mathrm{H}, \mathrm{dd}, J=1.9,8.6 \mathrm{~Hz}) .{ }^{13} \mathrm{C}-\mathrm{NMR}$ $\left(101 \mathrm{MHz} \mathrm{CDCl}_{3}\right) \delta: 135.0,134.8,128.9$ (2C), 127.5 (2C), 126.9, 126.4, 126.2, 123.0, 122.8, $119.4,118.3,112.4$. HRMS (ESI): $m / z$ calc. for $\mathrm{C}_{15} \mathrm{H}_{9} \mathrm{ClN}[\mathrm{M}-\mathrm{H}]^{-}$: 226.0429; obt.: 226.0454 . 5-Chloro-3-(4-methoxyphenyl)-1H-indole (3r) [31]: Flash column chromatography on a silica gel (hexanes/ethyl acetate, $0 \rightarrow 93 / 7$ ) yielded the product as brown oil: $10 \%$ yield. ${ }^{1} \mathrm{H}$ NMR $\left(400 \mathrm{MHz}, \mathrm{CDCl}_{3}\right) \delta: 8.27(1 \mathrm{H}, \mathrm{bs}), 7.87-7.81(1 \mathrm{H}, \mathrm{m}), 7.57-7.48(2 \mathrm{H}, \mathrm{m}), 7.35-7.27$ $(2 \mathrm{H}, \mathrm{m}), 7.18(1 \mathrm{H} \mathrm{dd}, J=8.6,2.0 \mathrm{~Hz}), 7.03-6.97(2 \mathrm{H}, \mathrm{m}), 3.86(3 \mathrm{H}, \mathrm{s}) .{ }^{13} \mathrm{C}-\mathrm{NMR}(101 \mathrm{MHz}$, $\left.\mathrm{CDCl}_{3}\right) \delta: 158.3,134.9,132.7,128.6,127.4,127.0,125.9,122.6,122.4,119.2,117.9,114.4(2 \mathrm{C})$, 112.3, 55.4. HRMS (ESI): $m / z$ calc. for $\mathrm{C}_{15} \mathrm{H}_{11} \mathrm{NOCl}[\mathrm{M}-\mathrm{H}]^{-}: 256.0524$; obt.: 256.0561 .

5-Chloro-3-(4-fluorophenyl)-1H-indole (3s): Flash column chromatography on a silica gel (hexanes/ethyl acetate, 95/5 $\rightarrow$ 90/10) yielded the product as yellow oil: $21 \%$ yield. ${ }^{1} \mathrm{H}$ $\operatorname{NMR}\left(400 \mathrm{MHz}, \mathrm{CDCl}_{3}\right) \delta: 8.26(1 \mathrm{H}, \mathrm{bs}), 7.81(1 \mathrm{H}, \mathrm{d}, J=1.8 \mathrm{~Hz}), 7.58-7.50(2 \mathrm{H}, \mathrm{m}), 7.35-7.29$ $(2 \mathrm{H}, \mathrm{m}), 7.19(1 \mathrm{H}, \mathrm{dt}, J=8.7,1.6 \mathrm{~Hz}), 7.17-7.10(2 \mathrm{H}, \mathrm{m}) .{ }^{13} \mathrm{CNMR}\left(101 \mathrm{MHz}, \mathrm{CDCl}_{3}\right) \delta: 161.6$ $(\mathrm{d}, J=245.2 \mathrm{~Hz}), 134.9,130.8(\mathrm{~d}, J=3.3 \mathrm{~Hz}), 128.9(\mathrm{~d}, J=7.8 \mathrm{~Hz}), 126.8,126.2,122.8(2 \mathrm{C})$, 119.0 (2C), 117.3, $115.7(\mathrm{~d}, J=21.5 \mathrm{~Hz}, 2 \mathrm{C}), 112.4$. HRMS (ESI): $m / z$ calc. for $\mathrm{C}_{14} \mathrm{H}_{8} \mathrm{NClF}$ [M $-\mathrm{H}]^{-}: 244.0345$; obt.: 244.0324 .

5-Chloro-3-(4-(trifluoromethyl)phenyl)-1H-indole (3t) [29]: Flash column chromatography on a silica gel (hexanes/ethyl acetate, $0 \rightarrow 93 / 7$ ) gives the product as a light yellow solid: $30 \%$ yield; mp $125-128{ }^{\circ} \mathrm{C} .{ }^{1} \mathrm{H}-\mathrm{NMR}\left(400 \mathrm{MHz} \mathrm{CDCl}_{3}\right) \delta: 8.33(1 \mathrm{H}, \mathrm{bs}), 7.85(1 \mathrm{H}, \mathrm{d}, J=1.9 \mathrm{~Hz})$, $7.67(4 \mathrm{H}, \mathrm{s}), 7.39(1 \mathrm{H}, \mathrm{d}, J=2.6 \mathrm{~Hz}), 7.32(1 \mathrm{H}, \mathrm{d}, J=8.6 \mathrm{~Hz}), 7.21(1 \mathrm{H}, \mathrm{q}, J=3.6 \mathrm{~Hz}) .{ }^{13} \mathrm{C}-\mathrm{NMR}$ $\left(101 \mathrm{MHz} \mathrm{CDCl}_{3}\right) \delta: 138.5(1 \mathrm{C}, \mathrm{d}, J=1.1 \mathrm{~Hz}), 135.0,128.1(1 \mathrm{C}, \mathrm{q}, J=32.4 \mathrm{~Hz}), 127.3(3 \mathrm{C})$, $126.6,126.5,125.8(2 \mathrm{C}, \mathrm{q}, J=3.8 \mathrm{~Hz}), 123.8,123.1,119.0,116.8,112.6$. HRMS (ESI): $m / z$ calc. for $\mathrm{C}_{15} \mathrm{H}_{8} \mathrm{ClF}_{3} \mathrm{~N}[\mathrm{M}-\mathrm{H}]^{-}$: 294.0303; obt.: 294.0326 .

\subsection{Determination of the Minimum Inhibitory Concentration (MIC)}

The determination of the MIC was performed in sterile 96-well, clear round-bottom plates using the resazurin reduction microplate assay (REMA), as previously described [9]. Briefly, test compounds 3a-t were solubilized in 100\% DMSO (Sigma-Aldrich, St. Louis, $\mathrm{MO}, \mathrm{USA}$ ) to a concentration of $2 \mathrm{mg} / \mathrm{mL}$, and aliquots were kept at $-20{ }^{\circ} \mathrm{C}$. On the day of the assay, compound aliquots were thawed at room temperature and diluted in Middlebrook 7H9 liquid medium (Becton Dickinson, BD), containing 10\% $(v / v)$ BBLTM Middlebrook ADC enrichment (albumin, dextrose, and catalase, BD) and 5\% (v/v) DMSO, to concentrations limited by the solubility of each compound. Test compounds were two-fold serially diluted, resulting in a 10-point concentration range. Isoniazid (INH, ACROS) was used as the anti-TB drug control. Compounds had their activity evaluated against the Mtb H37Rv laboratory reference strain (ATCC 27294) and three multidrug resistant clinical isolates of $\mathrm{Mtb}$ (PT2, PT12, and PT20), which were isolated from patients 
in the Lisbon Health Region, Lisbon, Portugal [14]. The MIC was considered as the lowest compound concentration capable of preventing resazurin (Sigma-Aldrich) reduction, which is otherwise marked by a color switch from blue to bright pink. Assays were performed three times for each compound on different dates, and only the most frequent MIC value among the assays was reported in molar concentration $(\mu \mathrm{M})$.

\subsection{Cellular Evaluation}

Cellular viability determination was conducted after incubation of cells with the 3h, 3n, 3r and 3t compounds using both the 3-(4,5-dimethylthiazol-2-yl)-2,5-diphenyl-2Htetrazolium bromide (MTT) [15] and neutral red uptake (NRU) [16] methods. HepG2 and Vero cells were grown in Dulbecco's Modified Eagle Medium (DMEM-Invitrogen, Waltham, MA, USA) supplemented with 10\% inactivated fetal bovine serum (Invitrogen), $1 \%$ penicillin-streptomycin (Invitrogen), and $0.1 \%$ fungizone (Invitrogen). For the MTT and NRU assay, HepG2 $\left(4 \times 10^{3}\right.$ cells/well $)$ and Vero $\left(2 \times 10^{3}\right.$ cells / well $)$ cells were seeded in 96-well culture plates and incubated for $24 \mathrm{~h}$. $1 \mathrm{H}$-Indoles were diluted at concentrations of $30 \mu \mathrm{M}$ using DMSO $0.5 \%$ and were incubated with the cell lines for $72 \mathrm{~h}$ at $37{ }^{\circ} \mathrm{C}$. Importantly, $30 \mu \mathrm{M}$ was the maximum concentration allowed by the solubility of the molecules. For the MTT assay, after incubation for $72 \mathrm{~h}$ at $37{ }^{\circ} \mathrm{C}$ under $5 \% \mathrm{CO}_{2}$, the cultures were incubated with MTT solution $(5 \mathrm{mg} / \mathrm{mL})$ for $4 \mathrm{~h}$. The formazan crystals were dissolved with $100 \mu \mathrm{L}$ of DMSO. The absorbance was measured at $595 \mathrm{~nm}$ using an EZ Read 400 microplate reader (Biochrom, Holliston, MA, USA). The mean absorbance of negative control wells was set as $100 \%$ viability, and the values of treated cells were calculated as the percentage of vehicle control (0.5\% DMSO). The precipitated purple formazan crystals were directly proportional to the number of live cells with active mitochondria. For the NRU assay, after $72 \mathrm{~h}$ of cell incubation PBS was used to wash the cells and $200 \mu \mathrm{L}$ of neutral red dye solution ( $25 \mu \mathrm{g} / \mathrm{mL}$, Sigma) prepared in serum-free medium was added to the plate and incubated for $3 \mathrm{~h}$ at $37^{\circ} \mathrm{C}$ under $5 \% \mathrm{CO}_{2}$. Cells were washed with PBS followed by the addition of $100 \mu \mathrm{L}$ of a desorb solution (ethanol/acetic acid/water, 50:1:49) for 30 min with gently shaking to extract neutral red dye from the viable cells. Absorbance was measured at $562 \mathrm{~nm}$ (EZ Read 400 microplate reader (Biochrom, Holliston, MA, USA)), and the cell viability was expressed as a percentage, considering the vehicle control cell (0.5\% DMSO) as $100 \%$ cell viability.

\subsection{Genotoxicity}

The alkaline comet assay [17] was performed using HepG2 cells. The cells were seeded at $8 \times 10^{4}$ cells/well in a 24 -well culture plate for $24 \mathrm{~h}$ before treatment. After this time, compound $3 \mathrm{r}$ was added at concentrations of $20 \mu \mathrm{M}$ and $30 \mu \mathrm{M}$, and the plate was incubated for an additional $24 \mathrm{~h}$. Cells were mixed with low-melting point agarose and placed on a microscope slide precovered with normal agarose, and placed at $4{ }^{\circ} \mathrm{C}$ for $10 \mathrm{~min}$ for total agarose solidification. The microscope slides were then exposed to a lysis solution (2.5 M NaCl, $100 \mathrm{mM} \mathrm{Na} 2$ EDTA, $10 \mathrm{mM}$ Tris with 1\% Triton X-100, and 10\% DMSO) for $48 \mathrm{~h}$. The slides were washed with PBS and then exposed to alkali conditions ( $300 \mathrm{mM}$ $\mathrm{NaOH}, 1 \mathrm{mM}$ ethylenedinitrilotetraacetic acid, $\mathrm{pH}>13$ ) at $4{ }^{\circ} \mathrm{C}$ for $20 \mathrm{~min}$ in order to allow the DNA to unfold and the expression of alkali-labile sites to occur. Electrophoresis was then performed for $20 \mathrm{~min}$ at $25 \mathrm{~V}$ and $300 \mathrm{~mA}$. Subsequently, the slides were neutralized, fixed, and stained using silver nitrate staining. After they were completely dry, the cells were observed on a microscope. Incubation with methyl methanesulfonate (MMS) at $100 \mu \mathrm{M}$ was used as a positive control group. Overall, 100 cells from each slide, and two slides per treatment, were selected randomly for the analysis and for quantifying DNA damage. Slides were visually scored according to the size and amount of DNA present in the tail. Separately, each cell was given an arbitrary value of 0 (undamaged) to 4 (maximum damage). The damage score was thus attributed to each slide and ranged from 0 (undamaged: 100 cells $\times 0$ ) to 400 (maximum damage: 100 cells $\times 4$ ). Finally, damage score was expressed as the mean with standard error from two independent experiments. 


\subsection{Time-Kill Curves}

To observe the kill kinetics and the MBC of compound $3 r$ against the Mtb H37Rv, timekilling curves were performed as previously described [22]. First, an actively growing $\mathrm{Mtb}$ culture (OD600 $\approx 0.6-0.8$ ) was diluted to a theoretical OD of 0.1 in $7 \mathrm{H} 9$ broth supplemented with $10 \%$ ADC, $0.05 \%$ Tween- 80 , and $0.2 \%$ glycerol. Next, the former mycobacterial suspension was further diluted (1:500) in 7H9 broth to reach a cell density of approximately $10^{5} \mathrm{CFU} / \mathrm{mL}$. This second mycobacterial suspension was equally divided $(5 \mathrm{~mL})$ in $50 \mathrm{~mL}$ conical tubes (Corning ${ }^{\circledR}$, New York, NY, USA), each containing different concentrations of compound $3 \mathbf{r}(0.5,1.0,2.0$, or $4.0 \times$ the MIC value in liquid medium) in triplicate. Aliquots $(0.1 \mathrm{~mL})$ were taken from this second mycobacterial suspension on day zero, in triplicate, serially diluted in sterile $0.9 \%$ saline solution $\left(10^{-1}, 10^{-2}\right.$ and $\left.10^{-3}\right)$, and plated onto nonselective $7 \mathrm{H} 10$ agar plates, supplemented with $10 \%$ OADC and $0.5 \%$ glycerol, to determine the initial inoculum. The final concentration of DMSO was adjusted to $2.5 \%$ in all tubes. A tube containing DMSO only (no compound) was included as a growth control. The cultures were incubated under shaking $\left(37^{\circ} \mathrm{C}, 100 \mathrm{rpm}\right)$ for 21 days. Aliquots $(0.1 \mathrm{~mL})$ were taken from each tube on days 3, 7, 14 and 21 after inoculation, serially diluted in sterile $0.9 \%$ saline solution, and three dilutions were chosen to be spread $(0.1 \mathrm{~mL})$ onto 7H10 agar plates. The plates were incubated at $37^{\circ} \mathrm{C}$ for $2-3$ weeks until colonies were visible for $\mathrm{CFU}$ counting. The $\mathrm{CFU} / \mathrm{mL}$ values were converted to the logarithmic scale $\left(\log _{10}\right)$ and plotted as a function of the exposure time in days. A lower limit of detection of $200 \mathrm{CFU} / \mathrm{mL}$ for undiluted samples was fixed for this experiment. The MBC value was considered as the lowest compound concentration that resulted in 3 logs kill of Mtb over 21 days [22].

\subsection{Pharmacodynamic Model}

The maximum and minimum bacterial growth rates $(\psi)$ were obtained from the coefficient of a linear regression from the colony count of viable bacteria $(\mathrm{CFU} / \mathrm{mL})$ over 21 days of the time-kill curve of compound 3r. The Hill coefficient and zMIC results were obtained using the least squares method, using an algorithm to minimize the differences between the experimental values and the estimated values [23,24].

\subsection{Statistical Analysis}

Data were expressed as the mean \pm standard error of the mean. Statistical analysis was performed by one-way analysis of variance followed by Dunnett's post-test, using GraphPadPrism 5.0 software.

Supplementary Materials: The following are available online. Figures $\mathrm{S} 1-\mathrm{S} 40:{ }^{1} \mathrm{H}$ and ${ }^{13} \mathrm{C}$ spectra for compounds $3 \mathbf{a}-\mathbf{3 t}$.

Author Contributions: Funding acquisition: C.V.B., L.A.B. and P.M.; supervision: P.M.; writingoriginal draft preparation: R.J.E., R.S.R., B.L.A., N.S., C.E.N., F.F.S., M.D., L.D., F.S.M., M.A.P., R.V.L., C.V.B., L.A.B. and P.M.; writing - review \& editing: R.J.E., R.S.R., B.L.A., N.S. and P.M. All authors have read and agreed to the published version of the manuscript.

Funding: This research was funded by CNPq/FAPERGS/CAPES/BNDES, Brazil (grant numbers: 421703-2017-2/17-1265-8/14.2.0914.1) to C.V.B., L.A.B. and P.M. In addition, this study was financed in part by the Coordenação de Aperfeiçoamento de Pessoal de Nível Superior-Brasil (CAPES), Finance Code 001. C.V.B., L.A.B. and P.M. are Research Career Awardees of the National Research Council of Brazil (CNPq). Fellowships from CNPq (R.S.R., B.L.A., N.S. and L.D.) and CAPES (C.E.N., F.F.S., M.D. and F.S.M.) are also acknowledged.

Institutional Review Board Statement: Not applicable.

Informed Consent Statement: Not applicable.

Data Availability Statement: The data presented in this study are available in Supplementary Materials. 
Acknowledgments: We are grateful to Miguel Viveiros from the Universidade Nova de Lisboa (Lisbon, Portugal) for providing the M. tuberculosis clinical isolates used in this study.

Conflicts of Interest: The authors declare no conflict of interest.

Sample Availability: Samples of the synthesized compounds are available from the authors.

\section{References}

1. World Health Organization (WHO). Global Tuberculosis Report, 2020. Available online: https://www.who.int/publications/i/ item/9789240013131 (accessed on 18 August 2021).

2. Parish, T. In vitro drug discovery models for Mycobacterium tuberculosis relevant for host infection. Expert Opin. Drug Discov. 2020, 15, 349-358. [CrossRef] [PubMed]

3. Ferraris, D.M.; Miggiano, R.; Rossi, F.; Rizzi, M. Mycobacterium tuberculosis Molecular Determinants of Infection, Survival Strategies, and Vulnerable Targets. Pathogens 2018, 7, 17. [CrossRef] [PubMed]

4. Rode, H.B.; Lade, D.M.; Grée, R.; Mainkar, P.S.; Chandrasekhar, S. Strategies towards the synthesis of anti-tuberculosis drugs. Org. Biomol. Chem. 2019, 17, 5428-5459. [CrossRef] [PubMed]

5. Mikušová, K.; Ekins, S. Learning from the past for TB drug discovery in the future. Drug Discov. Today 2017, 22, 534-545. [CrossRef]

6. Williams, K.J.; Duncan, K. Current Strategies for Identifying and Validating Targets for New Treatment-Shortening Drugs for TB. Curr. Mol. Med. 2007, 7, 297-307. [CrossRef]

7. Bloemberg, G.V.; Keller, P.M.; Stucki, D.; Trauner, A.; Borrell, S.; Latshang, T.; Coscolla, M.; Rothe, T.; Hömke, R.C.; Feldmann, J.; et al. Acquired resistance to bedaquiline and delamanid in therapy for tuberculosis. N. Engl. J. Med. 2015, 373, 1986-1988. [CrossRef]

8. Pissinate, K.; Villela, A.D.; Rodrigues-Junior, V.; Giacobbo, B.C.; Grams, E.S.; Abbadi, B.L.; Trindade, R.V.; Nery, L.R.; Bonan, C.D.; Back, D.F.; et al. 2-(Quinolin-4-yloxy)acetamides are active against drug-susceptible and drug-resistant Mycobacterium tuberculosis strains. ACS Med. Chem. Lett. 2016, 7, 235-239. [CrossRef]

9. Giacobbo, B.C.; Pissinate, K.; Rodrigues-Junior, V.; Villela, A.D.; Grams, E.S.; Abbadi, B.L.; Subtil, F.T.; Sperotto, N.; Trindade, R.V.; Back, D.F.; et al. New insights into the SAR and drug combination synergy of 2-(quinolin-4-yloxy)acetamides against Mycobacterium tuberculosis. Eur. J. Med. Chem. 2017, 126, 491-501. [CrossRef]

10. Macchi, F.S.; Pissinate, K.; Villela, A.D.; Abbadi, B.L.; Rodrigues-Junior, V.; Nabinger, D.D.; Altenhofen, S.; Sperotto, N.; Dadda, A.; Subtil, F.T.; et al. 1H-Benzo[d]imidazoles and 3,4-dihydroquinazolin-4-ones: Design, synthesis and antitubercular activity. Eur. J. Med. Chem. 2018, 155, 153-164. [CrossRef]

11. Reddy, G.S.; Pal, M. Indole Derivatives as Anti-Tubercular Agents: An Overview on their Synthesis and Biological Activities. Curr. Med. Chem. 2020, 28, 4531-4568. [CrossRef]

12. Kumar, S.; Ritika. A brief review of the biological potential of indole derivatives. Future J. Pharm. Sci. 2020, 6, 121. [CrossRef]

13. Joucla, L.; Batail, N.; Djakovitcha, L. “On Water" Direct and Site-Selective Pd-Catalysed CH Arylation of (NH)-Indoles. Adv. Synth. Catal. 2010, 352, 2929-2936. [CrossRef]

14. Perdigão, J.; Silva, H.; Machado, D.; Macedo, R.; Maltez, F.; Silva, C.; Jordao, L.; Couto, I.; Mallard, K.; Coll, F.; et al. Unraveling Mycobacterium tuberculosis genomic diversity and evolution in Lisbon, Portugal, a highly drug resistant setting. BMC Genom. 2014, 15, 991. [CrossRef]

15. van Meerloo, J.; Kaspers, G.J.; Cloos, J. Cell Sensitivity Assays: The MTT Assay. Methods Mol. Biol. 2011, 731, 237-245. [PubMed]

16. Repetto, G.; del Peso, A.; Zurita, J.L. Neutral red uptake assay for the estimation of cell viability/cytotoxicity. Nat. Protoc. 2008, 3, 1125-1131. [CrossRef]

17. Kumaravel, T.S.; Vilhar, B.; Faux, S.P.; Jha, A.N. Comet Assay measurements: A perspective. Cell Biol. Toxicol. 2009, $25,53-64$. [CrossRef]

18. Czock, D.; Keller, F. Mechanism-based pharmacokinetic-pharmacodynamic modeling of antimicrobial drug effects. J. Pharmacokinet. Pharmacodyn. 2007, 34, 727-751. [CrossRef]

19. Mueller, M.; de la Peña, A.; Derendorf, H. Issues in Pharmacokinetics and Pharmacodynamics of Anti-Infective Agents: Kill Curves versus MIC. Antimicrob. Agents Chemother. 2004, 48, 369-377. [CrossRef]

20. Sim, J.H.; Jamaludin, N.S.; Khoo, C.-H.; Cheah, Y.-K.; Binti, S.N.; Halim, A.; Seng, H.-L.; Tiekink, E.R.T. In vitro antibacterial and time-kill evaluation of phosphanegold(I) dithiocarbamates, $\mathrm{R} 3 \mathrm{PAu}\left[\mathrm{S}_{2} \mathrm{CN}(\mathrm{iPr}) \mathrm{CH}_{2} \mathrm{CH}_{2} \mathrm{OH}\right]$ for $\mathrm{R}=\mathrm{Ph}$, $\mathrm{Cy}$ and Et, against a broad range of Gram-positive and Gram-negative bacteria. Gold Bull. 2014, 47, 225-236. [CrossRef]

21. de Steenwinkel, J.E.M.; de Knegt, G.J.; ten Kate, M.T.; van Belkum, A.; Verbrugh, H.A.; Kremer, K.; van Soolingen, D.; BakkerWoudenberg, I.A.J.M. Time-kill kinetics of anti-tuberculosis drugs, and emergence of resistance, in relation to metabolic activity of Mycobacterium tuberculosis. J. Antimicrob. Chemother. 2010, 65, 2582-2589. [CrossRef]

22. Parish, T.; Roberts, D.M. Determination of Compound Kill Kinetics against Mycobacterium tuberculosis. In Mycobacteria Protocols, Methods in Molecular Biology, 3rd ed.; Springer Protocols: New York, NY, USA, 2015; Volume 1285, pp. $269-279$.

23. Foerster, S.; Unemo, M.; Hathaway, L.J.; Low, N.; Althaus, C.L. Time-kill curve analysis and pharmacodynamic modelling for in vitro evaluation of antimicrobials against Neisseria gonorrhoeae. BMC Microbiol. 2016, 16, 216. [CrossRef] 
24. Regoes, R.R.; Wiuff, C.; Zappala, R.M.; Garner, K.N.; Baquero, F.; Levin, B.R. Pharmacodynamic Functions: A Multiparameter Approach to the Design of Antibiotic Treatment Regimens. Antimicrob. Agents Chemother. 2004, 48, 3670-3676. [CrossRef]

25. Chen, S.; Liao, Y.; Zhao, F.; Qi, H.; Liu, S.; Deng, G.-J. Palladium-Catalyzed Direct Arylation of Indoles with Cyclohexanones. Org. Lett. 2014, 16, 1618-1621. [CrossRef]

26. Zhang, Y.-P.; Feng, X.-L.; Yang, Y.-S.; Cao, B.-X. Metal-free, C-H arylation of indole and its derivatives with aryl diazonium salts by visible-light photoredox catalysis. Tetrahedron Lett. 2016, 57, 2298-2302. [CrossRef]

27. Bellina, F.; Benelli, F.; Rossi, R. Direct Palladium-Catalyzed C-3 Arylation of Free (NH)-Indoles with Aryl Bromides under Ligandless Conditions. J. Org. Chem. 2008, 73, 5529-5535. [CrossRef]

28. Chen, Y.; Guo, S.; Li, K.; Qu, J.; Yuan, H.; Hua, Q.; Chen, B. Palladium-Catalyzed Direct Denitrogenative C-3-Arylation of 1H-Indoles with Arylhydrazines using Air as the Oxidant. Adv. Synth. Catal. 2013, 355, 711-715. [CrossRef]

29. Andersen, K.; Perregaard, J.; Arnt, J.; Nielsen, J.B.; Bergtrup, M. Selective, Centrally Acting Serotonin 5-HT 2 Antagonists. 2. Substituted 3-(4-Fluorophenyl)-1H-indoles. J. Med. Chem. 1992, 35, 4823-4831. [CrossRef] [PubMed]

30. Ragaini, F.; Rapetti, A.; Visentin, E.; Monzani, M.; Caselli, A.; Cenini, S. Synthesis of Indoles by Intermolecular Cyclization of Unfunctionalized Nitroarenes and Alkynes, Catalyzed by Palladium-Phenanthroline Complexes. J. Org. Chem. 2006, 71, 3748-3753. [CrossRef] [PubMed]

31. Yang, R.; Yu, J.-T.; Sun, S.; Zheng, Q.; Cheng, J. Copper-mediated intramolecular aza-Wacker-type cyclization of 2-alkenylanilines toward 3-aryl indoles. Tetrahedron Lett. 2017, 58, 445-448. [CrossRef] 